\title{
PENGARUH PENJADWALAN TERHADAP KINERJA PEGAWAI YANMA POLDA LAMPUNG
}

\author{
Riska Maylina ${ }^{(1)}$, Fahrizi $^{(2)}$, Khairul Saleh $^{(3)}$ \\ Fakultas Ekonomi Universitas Sang Bumi Ruwa Jurai \\ riska.maylinaa@gmail.com,fahrizi@fe.saburai.ac.id, khairul.saleh@fe.saburai.ac.id
}

\begin{abstract}
Abstrak. Masalah dalam penelitian ini adalah bagaimana penjadwalan Yanma Polda Lampung dan bagaimana pengaruh antara penjadwalan terhadap kinerja Pegawai Yanma Polda Lampung. Tujuan penelitian ini adalah untuk mengetahui penjadwalan Yanma Polda Lampung dan untuk mengetahui pengaruh antara penjadwalan terhadap Kinerja Pegawai Yanma Polda Lampung. Tujuan penelitian ini adalah untuk mengetahui pengaruh antara Penjadwalan terhadap Kinerja Yanma Polda Lampung di Bandar Lampung. Hipotesis penelitian dinyatakan dengan "Ada pengaruh antara Penjadwalan terhadap Kinerja Yanma Polda Lampung di Bandar Lampung”. Pengumpulan data penelitian menggunakan teknik sampel penelitian dari 25 responden. Metode penelitian yang digunakan adalah analisis kualitatif dan analisis kuantitatif yaitu regresi linier sederhana. Berdasarkan hasil analisis diperoleh persamaan bahwa $\mathrm{Y}=-0.672+0.633 \mathrm{X}$. Penjadwalan memiliki pengaruh yang besar yaitu sebesar 80,8 \% terhadap kinerja Pegawai di Yanma Polda Lampung di Bandar Lampung.
\end{abstract}

Kata kunci: Jadwal, Kinerja, Pegawai, Regresi.

\section{PENDAHULUAN}

Kecepatan dan ketepatan kerja merupakan suatu faktor yang diharapkan setiap departemen, lembaga maupun instansi dalam beroperasi. Kecepatan kerja merupakan faktor yang menentukan banyak pekerjaan yang diselesaikan oleh suatu instansi dengan batasan tertentu. Ketepatan kerja adalah faktor sasaran dari penyelesaian suatu masalah dalam suatu instansi untuk penyelesaian setiap masalah pada kriteria tertentu. Kedua faktor tersebut menjadi penting dan memiliki resiko pada saat dilaksanakan pada setiap operasi suatu instansi.

Faktor-faktor tersebut dapat dicapai dengan keakuratan yang baik jika ditunjang dengan suatu sistem terstruktur. Sistem terstruktur dibuat berdasarkan Visi dan Misi instansi tersebut yang berpedoman pada model operasi instansi. Tingkat kerumitan yang tinggi kerap kali terlihat pada proses perumusan sistem kerja yang ada pada instansi Tingkat kerumitan tersebut disusun berdasarkan kepentingan dan sasaran yang dihadapi. Sehingga segala sesuatu yang terjadi dapat terprediksi bentuk penyelesaiannya.

Paparan di atas menggambarkan perlunya suatu teknik yang baik dan tepat dilakukan dalam proses penyusunan kegiatan suatu instansi. Teknik sederhana yang dapat dilakukan instansi salah satunya adalah penjadwalan. Penjadwalan adalah suatu teknik sederhana dalam menyederhanakan penyelesaian permasalahan departemen, lembaga ataupun instansi dengan cara menyusun kegiatan berdasar kepentingan dalam waktu, beban pekerjaan dan pemposisian tenaga kerja.

Bentuk awal dari penjadwalan yang bersifat sederhana adalah memposisikan pekerjaan yang rutin dan insidental. Penyusunan pekerjaan ini tidak lepas dari sistem manajemen yang berlaku di instansi tersebut. Sistem manajemen memiliki peran utama dalam penyusunan jadwal kegiatan operasi. Oleh karena itu Penyusunan jadwal harus dilakukan dengan seksama yang diharapkan tidak akan menurunkan 
kemampuan kerja, dan dapat mencapai target pekerjaan yang diharapkan.

Proses penjadwalan yang penting memberikan ide pada peneliti dalam menyelesaikan salah satu syarat kelulusan Strata Satu, yaitu pada penulisan tugas penelitian ilmiah sederhana berupa skripsi. Penelitian yang dilakukan peneliti menggunakan obyek penelitian yaitu Yanma Polda Lampung di Bandar Lampung. Obyek dipilih penulis dengan dasar pertimbangan peneliti dalam membuktikan bahwa penjadwalan merupakan salah satu faktor penting yang dapat memajukan instansi tersebut.

Fenomena tersebut mengakibatkan penulis bermaksud meneliti secara lebih lanjut mengenai penelitian dengan judul :

"Pengaruh Penjadwalan terhadap Kinerja Yanma Polda Lampung di Bandar Lampung”.

\section{KAJIAN TEORI}

\section{Penjadwalan}

Penjadwalan (scheduling) merupakan salah satu kegiatan penting dalam perusahaan. Dalam suatu perusahaan industri penjadwalan diperlukan dalam mengalokasikan tenaga operator, mesin dan peralatan produksi, urutan proses, jenis produk, pembelian material, dan sebagainya (Handoko, 2015). Dalam suatu lembaga pendidikan, penjadwalan diperlukan untuk mengalokasikan ruang kelas, peralatan mengajar, tenaga pengajar, staf administrasi, pendaftaran penerimaan mahasiswa baru, dan sebagainya. Demikian pula dalam kegiatan perhotelan, penjadwalan diperlukan dalam pengaturan kamar hotel, ruang seminar/resepsi, menu makanan, ataupun acara entertainment. Terlepas dari jenis perusahaannya, setiap perusahaan perlu untuk melakukan penjadwalan sebaik mungkin agar memperoleh utilitasi maksimum dari sumber daya produksi dan asset lain yang dimiliki.

Penjadwalan adalah pengaturan waktu dari suatu kegiatan operasi. Penjadwalan mencakup kegiatan mengalokasikan fasilitas, peralatan ataupun tenaga kerja bagi suatu kegiatan operasi dan menentukan urutan pelaksanaan kegiatan operasi. Dalam hierarki pengambilan keputusan, penjadwalan merupakan langkah terakhir sebelum dimulainya operasi (Handoko, 2015).

Seperti telah dibahas pada awal buku ini, kegiatan operasi dimulai dari perencanaan jangka panjang yang meliputi perencanaan fasilitas dan kebutuhan peralatan. Selanjutnya, dilakukan perencanaan jangka menengah dimana keputusan yang berkaitan dengan penggunaan fasilitas, tenaga kerja, dan subkontrak dibuat. Dari perencanaan jangka menengah (perencanaan agregat) disusun suatu jadwal induk yang memerinci rencana agregat dan mengembangkan suatu jadwal menyeluruh (overall schedule) untuk produk yang akan dibuat, Jadwal menyeluruh menjabarkan perencanaan kapasitas dan jadwal induk kedalam perencanaan jangka pendek yang meliputi penugasan khusus untuk tenaga kerja, bahan dan mesin (Handoko, 2015).

Tujuan penjadwalan untuk meminimalkan waktu proses, waktu tunggu langganan, dan tingkat persediaan, serta penggunaan yang efisien dari fasilitas, tenaga kerja, dan peralatan. Penjadwalan disusun dengan mempertimbangkan berbagai keterbatasan yang ada. Penjadwalan yang baik akan memberikan dampak positif, yaitu rendahnya biaya operasi dan waktu pengiriman, yang akhirnya dapat meningkatkan kepuasan pelanganan. 


\section{Penjadwalan sebagai Fungsi Sistem Volume Produksi}

Berbagai teknik dapat diterapkan untuk penjadwalan. Teknik yang digunakan tergantung dari vulome produksi, variasi produk, keadaan operasi, dan kompleksitas dari pekerjaan sendiri. Pemilihan teknik juga tergantung dari penmgendalian yang diperlukan selama proses, misalnya perlunya pengendalaian terhadap waktu kosong dari mesin yang biaya operasinya tinggi, atau pengendalian terhadap persediaan dalam proses (Herjanto, 2013).

Penjadwalan sering dilihat sebagai fungsi dari sistem volume produksi, karena masing-masing tingkat volume produksi memiliki karakteristik yang berbeda sehingga menyebabkan pendekatan yang berbeda pula dalam perencanaan penjadwalan, teknik penjadwalan berdasarkan sistem volume produksi (Herjanto, 2013).

Seperti telah dibahas sistem volume produksi dapat dibagi dalam tiga kelompok, yaitu sistem volume tinggi, menengah dan rendah, Sistem volume tinggi mempunyai ciri standarisasi peralatan dan kegiatan yang sama, contohnya pembuatan kendaraan bermotor, radio, televisi, dan peralatan kantor. Penggunaan peralatan khusus, baik untuk produksi maupunm material handling, dan pembagian tenaga kerja dilakukan untuk meningkatkan alur kerja.

Teknik penjadwalan yang banyak digunakan dalam sistem volume tinggi adalah penyeimbangan lini (line balancing). Penyeimbangan lini menekankan kepada pengalokasian tugas-tugas kepada stasiunstasiun kerja sehingga terdapat keseimbangan waktu kerja diantara stasiun kerja tersebut. Sistem yang memiliki kesimbangan tinggi menghasilkan utilisasi yang maksimal baik untuk peralatan maupun personel, seperti juga rata-rata keluarannya.
Sistem vulome produksi menengah merupakan sistem volume produksi diantara volume tinggi dan volume rendah, yang terjadi karena permintaan atau rencana produksi yang cukup besar, tetapi masih belum cukup untuk dibuat massal.

Produksi dilakukan secara bervariasi antara pemenuhan pesanan (make to order) atau untuk persediaan (make to inventory). Sistem ini ditandai dengan pembuatan produk berdasarkan tumpukan (batch) dan menggunakan fasilitas yang sama untuk memproses berbagai jenis produk. Pesoalan yang muncul, bagaimana melakukan penjadwalan produksi dari beberapa produk dengan menggunakan fasilitas yang sama tadi.

Keputusan yang dihadapi manajer dalam sistem produksi yang demikian ialah menentukan jumlah yang diproduksi untuk setiap batch dan urutan pembuatan produk tersebut. Teknik penjadwalan yang sering digunakan dalam batch production ialah penjadwalan melalui metode run-out time (waktu habis). Metode ini mendasarkan keputusan kepada perkiraan waktu dimana persediaan akan habis (Herjanto, 2013).

\section{Pengertian Kinerja}

Kinerja adalah apa yang dilakukan dan tidak dilakukan karyawan yang mempengaruhi seberapa banyak mereka memberi kontribusi kepada organisasi yang antara lain termasuk kuantitas output, kualitas output, jangka waktu output, kehadiran di tempat kerja dan sikap kerja (Kartajaya, 2015).

Konsep ini merupakan variable dependen atau tidak bebas dan merupakan tujuan dari apa yang diharapkan dan beberapa teori pendukung digunakan untuk memperkuat hubungan dan kebijakan.

As'ad (2014) dalam bukunya Psikologi Industri mengutip pengertian kepuasan kerja menurut Blum, Wexley dan Yukl serta Tiffin. Blum (2012) mengemukakan 
bahwa kepuasan kerja merupakan sikap umum yang merupakan hasil dari beberapa sikap khusus terhadap faktor-faktor pekerjaan, penyesuain diri dan hubungan sosial individual di luar kerja.

Wexley dan Yukl (2012) mengemukakan bahwa kepuasan kerja adalah perasaan karyawan terhadap pekerjaannya. Tiffin pada tahun 1958 berpendapat bahwa kepuasan kerja berhubungan erat dengan sikap karyawan terhadap pekerjaannya sendiri, situasi kerja, kerjasama antar pimpinan dengan sesama karyawan.

Locke

(Muchinsky,

mendefinisikan kepuasan kerja sebagai suatu keadaan menyenangkan atau posistif yang berasal dari pengalaman kerja seseorang dari pekerjaannya. Sedangkan Greenberg dan Baron (2012) menyatakan bahwa kepuasan kerja adalah reaksi kognitif, afektif, dan penilaian orang terhadap pekerjaannya. Ada beberapa faktor-faktor yang mempengaruhi kepuasan kerja yaitu faktor finansial, fisik, sosial, dan psikologis (As'ad, 2014).

\section{METODE PENELITIAN}

\section{Objek Penelitian}

Penelitian ini dilakukan di Yanma Polda Lampung, yang beralamatkan di Jln. WR Supratman No. 1 Bandar Lampung. Penelitian ini dilakukan selama bulan AprilMei 2018 di Kantor Yanma Polda Lampung di Bandar Lampung.

\section{Metode dan Teknik Pengumpulan Data}

Dalam penelitian ini jenis data yang diperlakukan adalah :

\section{a. Data Primer}

Data primer merupakan data dasar yang akan diperoleh langsung tanpa perantara orang atau lembaga lain sebagai pihak ketiga. Data primer ini diperoleh dengan wawancara melalui responden dengan menggunakan daftar pertanyaan.

\section{b. Data Sekunder}

Data skunder merupakan data yang diperoleh melalui orang lain yang berhubungan dengan permasalahan yang dipecahkan. Data sekunder ini diperoleh melalui cara studi dokumenter yaitu mengumpulkan dan mempelajari brosurbrosur serta dokumen organisasi.

Langkah-langkah pengumpulan data yang penulis lakukan dengan mengadakan penelitian lapangan yaitu Penelitian yang dilakukan di Kantor Yanma Polda Lampung, adapun teknik yang digunakan dalam pengumpulan data adalah dengan :

1. Observasi, yaitu mengadakan survey atau pengamatan langsung kelokasi penelitian.

2. Interview atau wawancara, yaitu mengadakan tanya jawab langsung dengan pegawai pada Kantor Yanma Polda Lampung.

3. Dokumentasi, yaitu mengumpulkan dan mencatat dokumentasi yang relevan.

4. Quisioner, yaitu membuat pertanyaan yang berhubungan dengan varibael penelitian.

\section{Sampel dan Populasi}

Untuk menentukan populasi dan sampel Arikunto (2012) menyatakan ukuran minimum sampel untuk keperluan penelitian ini lebih dari 100 orang diambil sebanyak $10 \%$ dari jumlah keseluruhan populasi.

Pada penelitian ini sampel diambil dari jumlah populasi Staff Yanma Polda Lampung di Bandar Lampung (Arikunto, 2012). Populasi yang akan diteliti oleh penulis adalah responden yang berupa Staff Yanma Polda Lampung di Bandar Lampung secara kolektif dengan pengisian angket atau observasi, yaitu dengan 
mengambil sampel berdasarkan kegiatan dari cluster atau dalam kondisi normal dan mau memberikan jawaban pada angket yang diberikan. Dalam peneilitian ini sampel populasi digunakan dalam analisis data dan dapat diartikan menggunakan sampel jenuh sejumlah 25 responden.

\section{Metode Analisis Data}

Analisis kuantitatif yang dilakukan berdasarkan data primer yang diperoleh dari penyebaran instrument (daftar pertanyaan) kepada sampel, dan untuk mengetahui pengaruh dari variabel bebas (independent variable) terhadap variabel terikat (dependent variable).

Persamaan Regresi Linear Sederhana menentukan persamaan regresi linear sederhana untuk $\mathrm{X}$ :

$$
Y=a+b X+e
$$

Keterangan:

$$
\begin{aligned}
& \mathrm{Y}=\text { Kinerja Pegawai } \\
& \mathrm{a}=\text { Konstanta } \\
& \mathrm{b}=\text { Koefisien regresi } \mathrm{X} \\
& \mathrm{X}=\text { Penjadwalan } \\
& \mathrm{e}=\text { Faktor kesalahan }
\end{aligned}
$$

Untuk mengetahui besarnya pengaruh, penghitungan koefisien korelasi tersebut kemudian dilanjutkan dengan Rumus Koefisien Determinasi atau Koefisien Penentu (KP):

$$
K P=(r)^{2} x 100 \%
$$

Untuk menguji secara hipotesis secara parsial digunakan Uji t dengan rumus :

$$
t_{\text {hitung }}=\frac{r \sqrt{N-2}}{\sqrt{1-r^{2}}}
$$

Keterangan:

$$
\begin{array}{ll}
\mathrm{t}_{\text {hitung }} & =\text { Nilai } \mathrm{t} \\
\mathrm{r} & =\text { Koefisien Korelasi } \\
\mathrm{N} & =\text { Jumlah responden }
\end{array}
$$

Kriteria untuk Uji $t$ adalah sebagai berikut :

a) Jika $t_{\text {hitung }}>t_{\text {tabel }}$ maka Ha diterima dan Ho ditolak.

b) Jika $t_{\text {hitung }} \leq \mathrm{t}_{\text {tabel }}$ maka Ha ditolak dan Ho diterima.

\section{HASIL DAN PEMBAHASAN}

Secara umum, analisis regresi adalah studi mengenai ketergantungan variabel terikat dengan satu atau lebih variabel penjelas atau bebas (Arikunto, 2012). Analisis regresi digunakan untuk mengetahui apakah suatu variabel dapat dipergunakan untuk memprediksi atau meramal variabel-variabel lain. Yang menjadi perhatian dalam analisis ini adalah upaya menjelaskan dan mengevaluasi hubungan antara suatu variabel dengan satu atau lebih variable bebas. Hasil analisis regresi berupa koefisien untuk masingmasing variabel bebasnya. Koefisien ini diperoleh dengan cara memprediksi nilai variabel terikat dengan suatu persamaan.

Data yang digunakan dalam analisis ini adalah data primer, yaitu data cross section yang diperoleh dari kuesioner tertulis dan sudah diolah oleh peneliti terdahulu. Data diambil pada tahun 2018 pada pegawai Yanma Polda Lampung di Bandar Lampung. Penelitian, dengan masalah penelitian pengaruh antara Penjadwalan terhadap Kinerja Pegawai Yanma Polda Lampung di Bandar Lampung. Dari hasil uji coba angket pada responden setara terhadap variabel-variabel yang akan diteliti kepada 25 responden setara,

\section{Uji Validitas}


Dari hasil pengujian menunjukan validitas (corrected item-total correlation) koefisien korelasi item pada variabel $\mathrm{X}_{1}$ seluruhnya valid. Sehingga pada uji reliabilitas semua item pernyataan variabel dilakukan uji berjumlah 5 butir. Hasil analisis uji reliabilitas yang terjadi menunjukkan bahwa kuesioner reliable, karena skor alpha positif dengan nilai 0.653 dan lebih besar dari 0.6 Arikunto (2012). Dengan demikian dapat dikatakan kuesioner variabel layak untuk digunakan dalam pengambilan data penelitian.

Dari hasil pengujian menunjukan validitas (corrected item-total correlation) koefisien korelasi item pada variabel $\mathrm{Y}$ seluruhnya valid dibawah 5\%. Hasil analisis uji reliabilitas menunjukkan bahwa kuesioner reliable, karena skor alpha positif dengan nilai 0.853 dan lebih besar dari 0.6 Arikunto (2012). Dengan demikian dapat dikatakan kuesioner variabel Y layak untuk digunakan dalam pengambilan data penelitian.

\section{Uji Normalitas dan Uji Homogenitas}

Hasil uji normalitas yang dilakukan dapat dilihat dengan hasil grafik normalitas, yang ditampilkan pada Gambar 1.

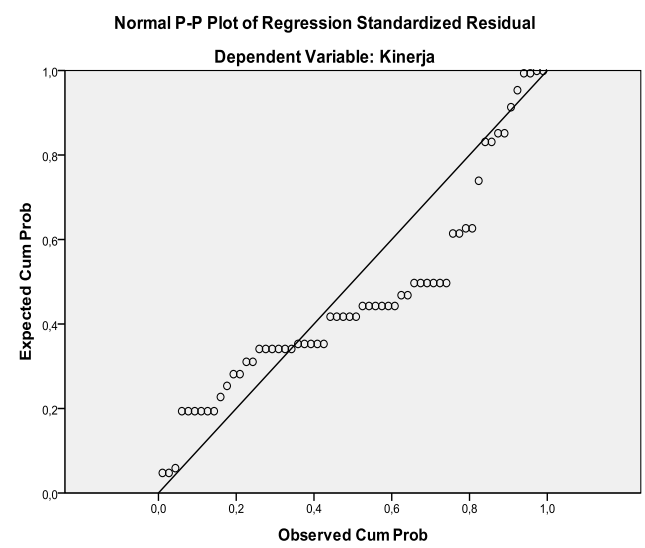

Gambar 1. Grafik Normalitas

Pola penyebaran yang terjadi berada pada sekitar garis diagonal dan mengikuti garis diagonal tersebut meskipun sedikit terpisah tetapi masih disekitaran sumbu normal. Ini berarti bahwa model regresi dalam penelitian ini sudah memenuhi asumsi normalitas dengan nilai moderate, yaitu variabel - variabel yang digunakan dalam penelitian ini mempunyai distribusi yang normal.

Untuk menguji homogenitas digunakan metode visual berdasarkan dengan melihat penyebaran nilai-nilai residual terhadap nilai prediksi ditunjukkan oleh Gambar 2.

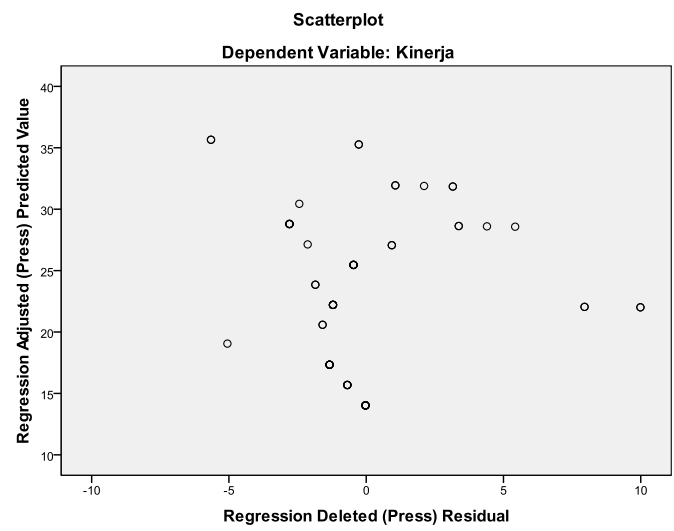

Gambar 2. Grafik Scatterplot

Berdasarkan seluruh gambar grafik di atas, diketahui bahwa penyebaran nilai nilai perbandingan tersebut tidak membentuk pola tertentu sehingga keadaan homogenitas dapat terpenuhi pada homogenitas Variabel X (Penjadwalan) dan Variabel Y (Kinerja Pegawai). Maka berdasarkan hasil uji data Normalitas dan Homogentitas data penelitian dapat dilanjutkan ke uji selanjutnya yaitu regresi.

\section{Analisis Kuantitatif}

Berdasarkan hasil uji tersebut maka didapatkan persamaan model regresi yang sebagai berikut :

$$
\begin{array}{ll}
\mathrm{Y} & =-0.672+0.633 \mathrm{X} 1 \\
\mathrm{t}_{\text {hitung }} & =(-0.416) \\
\mathrm{R}^{2} & =0.808
\end{array}
$$

Dari hasil regresi yang telah didapat, maka dapat hasil penelitian dapat 
diinterpretasikan pada Uji t yang dilakukan untuk melihat besarnya pengaruh secara individu variabel bebas terhadap variabel tak bebas. Dan hasil estimasi dapat kita lihat bahwa nilai t hitung untuk variabel $(\mathrm{X})$ sebesar 15.641 (Prob.sig. = 0,000) yang berarti t hitung $>\mathrm{t}$ tabel dengan tingkat signifikansi $95 \%$ (persen). Hal ini menunjukkan bahwa koefisien masing variabel bebas adalah penting secara statistik pengaruhnya terhadap variabel tak bebasnya atau dengan kata lain bahwa berpengaruh Signifikan. Kemudian koefisien determinasi $\mathrm{X}-\mathrm{Y}\left(\mathrm{R}^{2}\right)$ relatif sedang yaitu sebesar 0.808 Berarti bahwa $80,8 \%$ (persen) dari variasi perubahan pengaruh penjadwalan dapat menjelaskan kinerja pegawai di Yanma Polda Lampung di Bandar Lampung. Sedangkan 19.2\% (persen) sisanya adalah pengaruh dari variabel atau faktor-faktor lain diluar model.

Berdasarkan hasil analisis yang telah dilakukan dapat diinterpretasikan bahwa penjadwalan memiliki pengaruh yang besar yaitu sebesar (80,8 \%) terhadap kinerja pegawai di Yanma Polda Lampung di Bandar Lampung. Pada variabel penjadwalan juga didapatkan bahwa butir Ada target yang harus dicapai secara rutin memiliki kontribusi yang paling kecil. Kemudian Pada variabel kinerja pegawai butir yang paling kecil adalah Perintah kedinasan yang diberikan ditaati dan dilaksanakan oleh setiap pegawai. Dari pengolahan data juga didapatkan bahwa masih ada variabel lain tetapi tidak begitu besar pengaruhnya yang belum dimasukkan tetapi memiliki pengaruh pada Kinerja Pegawai sebesar $19.2 \%$.

\section{KESIMPULAN DAN SARAN}

\section{Kesimpulan}

Berdasarkan hasil analisis maka dapat disimpulkan bahwa penjadwalan memiliki pengaruh yang besar yaitu sebesar $(80,8 \%)$ terhadap kinerja pegawai di Yanma Polda Lampung di Bandar Lampung. Dari pengolahan data juga didapatkan bahwa masih ada variabel lain tetapi tidak begitu besar pengaruhnya yang belum dimasukkan tetapi memiliki pengaruh pada kinerja pegawai sebesar $19.2 \%$, dan signifikan hal ini terbukti dari nilai t hitung untuk variabel (X) sebesar 15.641 (Prob.sig. = 0,000) yang berarti $\mathrm{t}$ hitung $>\mathrm{t}$ tabel dengan tingkat signifikansi 95\% (persen). Maka dalam penelitian ini model menerima Hipotesis Alternatif dan menolak Hipotesis 0 dengan pengaruh yang besar.

\section{Saran}

Adapun saran yang diajukan peneliti diharapkan adanya penelitian lanjutan untuk memastikan pengaruh pada model yang terjadi. Hal ini terjadi disebabakan adanya faktor di luar model sebesar 19,2\%. Oleh sebab itu dibutuhkan penelitian lain guna mengembangkan model disebabkan sifat penelitian ini dapat mengalami perubahan seperti pada variabel Kompensasi, Insentif, Golongan dan Fasilitas Kerja yang tidak diteliti dalam penelitian ini.

\section{DAFTAR PUSTAKA}

Arikunto, Suharsimi. 2012. Prosedur Penelitian-Suatu Pendekatan Praktek. Jakarta: Penerbit Bina Aksara.

Asnawi, S. 2012. Teori Motivasi (Dalam Pendekatan Psikologi Industri dan Organisasi). Jakarta: Studia Press.

Deasler, Gary. 2015. Manajemen Sumber Daya Manusia. Jakarta: PT. Ghalia Indonesia. 
Flippo, Edwin B. 2014. Manajemen Sumber Daya Manusia. Jakarta: Penerbit Bina Aksara.

George, D and Mallery, P. 2013. SPSS/PC Step by Step a Simple Guide and Reference. Belenot: Wods Worbb Publishing Company.

Greenberg, J and Baron, R. 2014. Behavior in Organizations. New Jersey: Prentice Hall International, Inc.

Handoko, Hani. 2015. Manajemen dan Operasi. Yogyakarta: BPFE.

Herjanto, Eddy. 2014. Manajemen Produksi dan Operasi, Edisi 2. Jakarta: Grasindo.

Sugiono, 2017. Metode Penelitian. Bandung: Alfabeta.

Syadam, Gauzali. 2015. Manajemen Personalia Suatu Pendekatan Makro. Jakarta: Djambatan. 